\title{
Model Manajemen Pendidikan Adab Anak Usia Pendidikan Dasar di MIN Demangan Madiun Jawa Timur Indonesia
}

\author{
${ }^{1}$ Katni, ${ }^{2}$ Sigit Dwi Laksana \\ 12Universtas Muhammadiyah Ponorogo \\ Email: Katni2459@gmail.com
}

\begin{abstract}
This article discusses the model of adab education management in MIN Demangan, Madiun City with research findings that the management model of adab education strategy for children of basic education is as follows: 1) Using stages of planning and setting adab; 2) The implementation begins with organizing, coordinating activities so that integration and support by all school stakeholders. (3) The stage of strengthening madrasa culture in adab education is control and evaluation. 4) At the follow-up stage an inventory of advantages and obstacles is carried out in the implementation and also analyzes the cultural form of madrasas in adab education that has been well implemented or that is difficult to realize.
\end{abstract}

Keywords: Adab, Child, Adab Education Management Model

\section{Pendahuluan}

Pandangan hidup (worldview) merupakan asas dari setiap aktivitas, termasuk aktifitas keilmuan. Kegiatan pendidikan Islam dan teori-teorinya penting memiliki landasan Islamic worldview. Tujuan dan asasnya harus berdasarkan konsep-konsep dasar keIslaman. Pandangan hidup Islam adalah pemahaman seorang muslim terhadap konsep-konsep kunci dalam Islam, seperti konsep tentang Tuhan, wahyu, Nabi, manusia, alam, ilmu dan lain-lain. Lalu, menjadikan konsep-konsep kunci tersebut sebagai alat dasar dalam merancang falsafah pendidikan, praktek pendidikan Islam. Oleh sebab itu, dalam pembentukan akhlak sangat dipengaruhi oleh pandangan hidupnya.

Cara pandang, sikap dan adab seorang muslim dikendalikan oleh pemikirannya dalam memahami realitas kehidupan ini, baik realitas fisik maupun metafisik. Seorang muslim yang memiliki visi keakhiratan memiliki perspektif berbeda dengan seorang yang bervisi keduniawian saja dalam melihat setiap realitas dalam kehidupannya. Alparslan Acikgence, seorang pakar Filsafat Islam berkebangsaan Turki menyatakan, pikiran itu menjadi motor perbuatan. ${ }^{1}$

Seorang pencari ilmu yang baik menancapkan niat belajarnya dalam hatinya untuk mencari ridha Allah SWT. Bukan sekedar mencari pencapaian-pencapaian yang bersifat pragmatis. Seperti berambisi mengejar gelar, popularitas, pekerjaan, pendapatan yang besar, menepati sebuah jabatan atau kekuasaan. Ia menempatkan visi keakhiratan dan ketuhanan di atas segalanya. Keyakinan bahwa ridha Allah SWT jauh lebih berharga dari sekedar jabatan, uang, popularitas dalam kompetisi bergengsi. Ia memiliki tujuan tersebut karena memiliki keyakinan yang tepat. Inilah yang dimaksudkan oleh pendidikan Islam. Dimana visi ketuhanan dan keakhiratan menjadi hal pertama dan utama dari tujuan-tujuan lainnya.

${ }^{1}$ Apparslan Acikgence, Islamic Science Towards A Definition (Kuala Lumpur: ISTAC, 2003). h. 29 
Buruknya perilaku seseorang dikendalikan oleh pemikirannya. Worldview adalah kepercayaan, perasaan dan apa-apa yang terdapat dalam pikiran orang yang berfungsi sebagai motor bagi keberlangsungan dan perubahan sosial dan akhlak pembentukan cara pandang ini tidak lain melalui aktifitas keilmuan dalam kerja pendidikan.

Pendidikan merupakan wadah pengembangan ilmu pengetahuan. Baik tidaknya masyarakat dikembalikan kepada benar tidaknya ilmu yang dipelajari. Manusia menjadi beradab karena mengamalkan ilmu dengan baik dan benar, bukan hanya memiliki ilmu saja. Manusia bi-adab (tidak beradab) dikarenakan ilmunya salah, atau ilmunya tidak ditempatkan pada hal yang tepat, baik dan benar. Kekeliruan dalam ilmu menyebabkan pemikiran tidak beradab. Adab adalah menempatkan sesuatu sesuai tempatnya yang benar. Seorang ulama' dihormati sebagaimana orang berilmu. Seorang santri diperlakukan sebagaimana santri. Seorang pejabat diperlakukan dan bekerja sesuai dengan tugas pokok dan fungsi jabatannya dengan baik dan benar. Sebuah pemikiran tidak beradab jika pemikiran tersebut tidak sesuai dengan epistemologi Islam. Misalkan problem pemikiran penyamaan agama satu dengan yang lainnya, menyetarakan laki-laki dan perempuan dalam salat dan dalam seluruh aktivitas hidup, tidak mempercayai sakralitas al-Qur'an tidak lain dan tidak bukan merupakan problem keyakinan dan adab dalam worldview Islam. Keyakinan yang rusak tidak mampu mengontrol pemikiran seseorang. Ketiadaan adab (the loss of adab) berasal dari sebuah keyakinan yang keliru. Meragukan orisinalitas al-Qur'an misalnya akan membuka pada sikap merendahkan terhadap tulisan huruf-huruf al-Qur'an yang termaktub dalam mushaf. Ia mengganggap al-Qur'an tidak asli lagi karena itu tulisan tentangan.

Naquib Al-Atas Seorang pemikir bersar Islam juga secara konsisten memperdebatkan dan menjelaskan bahwa tujuan pendidikan dalam Islam tidak hanya untuk menghasilkan warga negara yang baik, juga bukan saja pekerja yang baik, tetapi orang yang baik. Ia mengatakan: "the one who is sincerely conscious of his responsibilities towards the true God; who understands and fulfills his obligations to bimself and others in his society with justice, and who constantly strives to improve every aspect of himself towards perfection as a man of adab (insan adabi). ${ }^{2}$

Orang Baik adalah orang yang dengan tulus sadar akan tanggung jawabnya terhadap Tuhan yang benar; yang mengerti dan memenuhi kewajibannya kepada dirinya dan orang lain di masyarakatnya dengan keadilan, dan yang senantiasa berusaha memperbaiki setiap aspek dirinya menuju kesempurnaan sebagai manusia yang beradab (insan adabi).

Praktek pendidikan adab agar berhasil sangat membutuhkan role model (teladan), dan membutuhkan dukungan banyak pihak. Sinergi orang tua dan dan sekolah, ${ }^{3}$ menjadi

2 S.M.N. al-Attas, "Risalah Untuk Kaum Muslimin (Message to Muslims)." (A long manuscript dictated to his secretary, Maret 1973). h. 54.

${ }^{3}$ Sri Hartini, "Pendidikan Karakter Disiplin Siswa di Era Modern Sinergi Orang Tua dan Guru di MTS Negeri Kabupaten Klaten,” AL-ASASIYYA: Journal Of Basic Education 2, no. 1 (2017): h. 38-59. 
penentu dalam pendidikan adab anak usia pendidikan dasar. ${ }^{4}$ Institusi keluarga merupakan fondasi bagi kehidupan masyarakat. ${ }^{5}$ Keluarga yang mengalami disorientasi karena pengaruh materialism di era globalisasi ${ }^{6}$ yang tidak selalu kompatibel dengan nilainilai universal Islam sering menjadi problem pendidikan Islam. Gaya hidup hedonistik dan materialistik serta permisif sebagaimana banyak ditayangkan pada sinetron di berbagai televisi mempengaruhi perilaku anak-anak yang dalam usia imitatif.

Hal ini merupakan salah satu dampak yang ditimbulkan dari era globalisasi, kemajuan teknologi saat ini menjadi slah satu faktor penentu berkembangnya perilaku anak. $^{7}$ Seperti yang diketahui bahwa globalisasi ibarat seperti dua sisi mata uang yaitu positif dan negatif juga menjadi penyebab infiltrasi budaya (gaya hidup, teknologi, sikap, dll). Keberadaannya sedemikian cepat dan mudah saling bertukar tempat dan saling memengaruhi satu sama lain. Dampak negatif dari arus globalisasi yang terlihat miris adalah perubahan yang cenderung mengarah pada krisis moral dan akhlak, sehingga menimbulkan sejumlah permasalahan kompleks melanda negeri ini akibat moral. Dapat di contohkan mulai dari hal kecil seperti anak-anak sekolah yang membolos pada jam pelajaran, sampai dengan korupsi. Selain itu terdapat pula tindakan-tindakan kriminal yang setiap hari biasa kita lihat. Hal ini membuktikan bahwa krisis moral telah dan sedang melanda bangsa ini.

Madrasah sebagai lembaga pendidikan Islam menjadi tumpuan penjaga pedidikan Adab. Sebagaimana Madrasah Ibtidaiyah Negeri Demangan Madiun yang selanjutnya disingkat MIN Demangan Kota Madiun. Adab yang sangat terkait erat dengan kecerdasan emosional dan spiritual sangat berpengaruh dalam kesuksesan manusia di dunia dan akhirat. Oleh karenanya pendidikan adab, bagaikan tanah yang subur untuk menanam segala keterampilan hidup manusia menjagi exspet dibidang apa saja, jika telah memiliki adab akan menjadi manusia yang ramatan lil alamin disemua bidang yang dikerjakannya. Hal ini sejalan dengan apa yang disampaikan Baharuddin, bila sesuatu yang ada didalam diri manusia (jiwa) bertemu dengan dunia eksternal yang positif maka tumbuh menjadi jiwa yang positif, sehat, dan kuat. Sebaliknya bila sesuatu yang ada didalam diri manusia bertemu dengan dunia eksternal yang negatif, maka tidak bertumbuh kembang secara optimal, yang kemudian berkembang menjadi hawa nafsu dan syahwat saja dan akan ada banyak berbagai perbuatan yang negatife. ${ }^{8}$

${ }^{4}$ D. E. M. M. U. Karo-Karo, "Membangun Karakter Anak dengan Mensinergikan Pendidikan Informal dengan Pendidikan Formal," Elementary School Journal PGSD FIP UNIMED 1, no. 2 (2014): h. 13.

5 Imam Mustofa, "Keluarga Sakinah dan Tantangan Globalisasi," Al-Mawarid Journal of Islamic Law XVIII (2008). h. 227-48.

${ }^{6}$ Sita Acetylena, "Analisis Implementasi Kebijakan Pendidikan Karakter Di Perguruan Taman Siswa Kecamatan Turen Kabupaten Malang," Jurnal Kebijakan dan Pengembangan Pendidikan 1, no. 1 (2013). h. 56 .

${ }^{7} \mathrm{D}$ Ann McLachlan, "The Impact of Globalization on Internationally Mobile Families: A Grounded Theory Analysis," Journal of Theory Construction \& Testing 9, no. 1 (t.t.). 2014). h. 34

8 Baharuddin Baharuddin, Pendidikan dan Psikologi Perkembangan (Yogyakarta: Ar-Ruzz Media, 
MIN Demangan Madiun mengimplementasikan pendidikan adab memiliki keunikan dan keseriusan dalam pedidikan adab. Hal ini dibuktikan dengan melibatkan orang tua, kepala madrasah, komite, guru, tenaga kependidikan dan siswa untuk menyusun, menyepakati, melaksanakan dan mengevaluasi, mengendalikan dan meningkatkan pendidikan adab di MIN Demangan Madiun. Berdasarkan hal demikian artikel ini menjadi kajian untuk mengembangkan khasanah pendidikan Islam dibidang adab atau disebut karakter lebih popular dengan karakter.

\section{Metode Penelitian}

Penelitian ini menggunakan pendekatan penelitian kualitatif dengan jenis penelitian lapangan. Penelitian ini mengambil tempat di MIN Demangan Madiun. Metode pengumpulan data melalui wawancara, observasi dan dokumentasi. Metode Analisis data yang digunakan dalam penelitian ini adalah deskriptif-analitis, melalui proses induksi-interprtetasi-konseptualisasi. Analisis data yang demikian, mengikuti apa yang dikemukakan Bogdan yakni analisis data kualitatif merupakan proses mencari dan menyusun secara sistematis data yang diperoleh dari hasil wawancara, catatan lapangan, dan bahan-bahan lain, sehingga dapat dipahami dengan mudah, dan temuannya dapat diinformasikan kepada orang lain.'

\section{Hasil dan Pembahasan}

\section{Pentingnya Pendidikan Adab Bagi Anak Sekolah Dasar}

Pendidikan dalam UU No. 20 Tahun 2003 pasal 3 tentang Sistem Pendidikan Nasional berbunyi pendidikan nasional berfungsi mengembangkan kemampuan dan membentuk watak serta peradaban bangsa yang bermartabat dalam rangka mencerdaskan kehidupan bangsa bertujuan untuk berkembangnya pontensi peserta didik agar menjadi manusia yang beriman dan bertaqwa kepada Tuhan Yang Maha Esa, berakhlak mulia, sehat, berilmu, cakap, kreatif, mandiri, dan menjadi warga negara yang demokratis serta bertanggung jawab. ${ }^{10}$ Sebagaimana tertuang dalam sila kedua yakni kemanusiaan yang adil dan beradab. ${ }^{11}$ Nilai kemanusiaan yang adil dan beradab dapat dilakukan melalui pelaksanaan kegiatan belajar mengajar di kelas yang terintegrasi dalam mata pelajaran kelompok pengembangan kepribadian, dan faktor-faktor yang mempengaruhi implementasi nilai kemanusiaan yang adil dan beradab adalah keteladanan guru dan pembina, tanggung jawab, dan kedisiplinan. ${ }^{12}$

${ }_{9}^{9}$ Muslimin Machmud, Tuntunan Penulisan Tugas Akhir Berdasarkan Prinsip Dasar Penelitian Ilmiah (Malang: Selaras, 2016). h. 75

10 Undang-Undang Republik Indonesia No. 20 Tabun 2003 Tentang Sistem Pendidikan Nasional (Bandung: Citra Umbara, 2003).

11 Undang-Undang Republik Indonesia No. 20 Tabun 2003 Tentang Sistem Pendidikan Nasional.

12 Hadi Rianto, "Implementasi Nilai Kemanusiaan Yang Adil Dan Beradab Di Lingkungan Sekolah,” Sosial Horizon: Jurnal Pendidikan Sosial 3, no. 1 (2016). h. 80-91. 
Pendidikan karakter dimaknai sebagai penanaman nilai-nilai karakter yang meliputi pembentukan kepribadian manusia menuju kearah yang lebih baik. pendidikan karakter mulai ditanamkan sedari kecil dari lingkungan keluarga yang merupakan pendidikan yang pertama dan utama. Dalam lingkup keluarga, seorang anak akan dibentuk karakter atau pola perilaku moralnya oleh orang tua yang terdiri dari ayah dan ibu. ${ }^{13}$ Konsep pendidikan adab penting untuk dilandasi landasan Islam diantaranya adalah sebagai berikut.

a. Penanaman nilai-nilai adab harus dilandasi dengan sebuah pengetahuan. Yakni diperkenalkan terlebih dahulu kepada anak didik sebelum nilai-nilai tersebut ditanamkan kepadanya. Pembentukan adab yang dilakukan oleh Rasulullah di landasi dan didasari dengan keteladanan (role model), sehingga dapat menumbuhkan kebaikan bagi dirinya sendiri maupun orang lain. Sebagai contoh tentang kesabaran Rasulullah shallallabu 'alaibi wa sallam dan akhlak beliau ketika berbicara dengan orang lain, sekalipun itu orang kafir. Rasulullah shallallabu 'alaibi wa sallam tetap mendengarkan dan tidak memotongnya meskipun beliau tidak menyukai hal tersebut. hal ini mengajarkan bahwa dengan memberikan contoh yang baik, maka orang lain akan mencoba untuk menerapkannya. hal ini sesuai dengan firman Allah surat Al-Ahzab, 33: 21 tentang akhlakul karimah Rasulullah yang berbunyi:

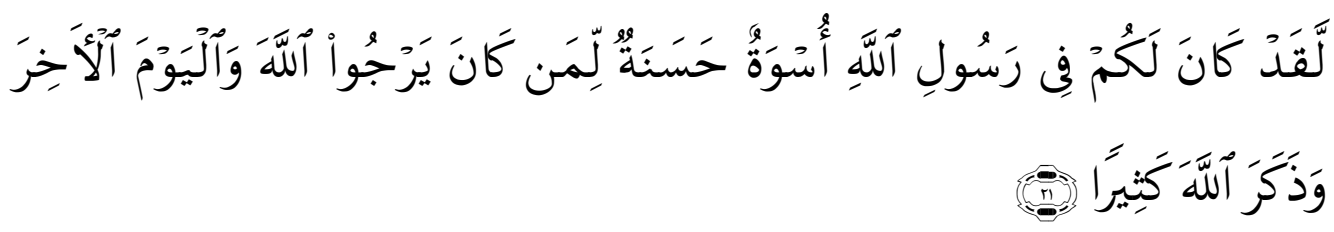

Artinya: "Sesunggubnya telah ada pada (diri) Rasulullab itu suri teladan yang baik bagimu (yaitu) bagi orang yang mengharap (rahmat) Allah dan (kedatangan) hari kiamat dan Dia banyak menyebut Allab”.

b. Pada pendidikan akhlak Rasulullah melakukannya secara bertahap, pelan tapi pasti. seperti contohnya ketika ketika Rasulullah mengajarkan shalat. Rasulullah memerintahkan anak pada usia 7 tahun sekedar diperintah untuk belajar tentang gerakan-gerakan dalam shalat, kalau anak tidak mau melaksanakan, maka si anak tidak perlu dipukul, hanya diberikan pengarahan bahwa shalat itu salah satu tiang agama. tetapi jika sudah mulai beranjak diusia 10 tahun, ketika anak mulai diperintah untuk shalat, anak tidak mau shalat, maka diperbolehkan untuk memukul anaknya. makna dari memukul ini berarti pendidikan kedisiplinan agar anaknya menjadi anak yang beragama, tetapi memukul disini juga dapat dimaksnai sebagai memukul secara fisik, tetapi pada bagian yang tidak membahayakan anak dan menyebabkan kesakitan, seperti punggung.

13 Sigit Dwi Laksana, "Urgensi Pendidikan Karakter Bangsa di Sekolah," Jurnal Muaddib 05, no. 01 (2015). h. 137. 
c. Sikap pendidikan akhlak yang ditunjukkan Rasulullah yaitu dengan menanamkan karakter kenabian yaitu siddiq (jujur), amanab (dapat dipercaya), tabligh (menyampaikan) dan fatonab (cerdas). Hal ini terlihat dari keseharian Rasulullah yang selalu dihiasi dengan indahnya akhlak, disamping itu Rasulullah juga sangat peduli terhadap anak-anak maupun para perempuan.

\section{Model Manajemen Pendidikan Adab anak Usia Pendidikan Dasar di Indonesia (Studi di MIN Demangan Kota Madiun)}

Menajemen Pendidikan Adab dalam penguatan budaya madrasah khususnya program madrasah dapat dilakukan dengan menggunakan pendekatan habitus. ${ }^{14}$ Nilai-nilai yang akan dijadikan budaya madrasah merupakan nilai-nilai tertentu yang telah disepakati bersama, yang harus dilaksanakan oleh segenap warga madrasah (stakeholder) termasuk didalamnya orang tua, membutuhkan pemahaman dan pembinaan sekolah, tentang pendidikan anaknya.

Berdasarkan hasil penelitian Roshonah bahwa program pelatihan parenting untuk meningkatkan pengetahuan, pemahamam, sikap dan perilaku serta keterampilan orangtua dalam mengasuh anak sangat penting untuk dilakukan. ${ }^{15}$

Nilai-nilai adab yang dibudayakan berbentuk norma, nilai-nilai, keyakinan, yang mereka pahami serta melandasi gagasan, semangat, perbuatan, dan karya seluruh warga madrasah. Program ini diarahkan sebagai upaya peningkatan prestasi belajar siswa baik yang behubungan dengan nilai akademik dan non akademik. Madrasah menciptakan iklim lingkungan (conditioning yang kondusif dalam menciptakan pendidikan yang efektif dan efisien. Langkah langkah manajemen pendidikan adab di MIN Demangan Kota Madiun adalah sebagai berikut.

a. Tahap Perencanaan dan penetapan

Tahap awal dalam melakukan penguatan budaya madrasah dalam pendidikan adab merupakan tahap perencanaan. Pada tahap ini dilakukan perumusan budaya madrasah, yang terdiri dari budaya adab madrasah dan budaya adab di kelas. Kegiatan perumusan budaya madrasah dilakukan dengan melibatkan stakeholder yang terdiri dari kepala madrasah, guru, pegawai dan komite. Kegiatan perumusan budaya madrasah dilakukan melalui musyawarah bersama untuk menghasilkan perencanaan rumusan budaya madrasah yang disepakati. Di samping itu, juga dirumuskan tata cara pelaksanaanya dan kegiatan monitoring dan evaluasi serta tindak lanjut yang akan dilakukan.

Rumusan budaya madrasah dalam pendidikan adab mengacu pada jenisjenis kegiatan, yang setidaknya memuat unsur-unsur: tujuan, sasaran kegiatan,

\footnotetext{
${ }^{14}$ Katni Katni, "Jilbab Dalam Al-Qur'an Dan Al-Hadits Serta Aplikasinnya Pada Pendidikan Islam Perspektif Teori Habitus Pierre Bourdieu," Al-ASASIYYA: Journal Of Basic Education 01, no. 01 (2016). h. 58.

15 Adiyati Fathu Roshonah, "Urgensi Program Pelatihan Parenting dalam Meningkatkan Kemampuan Komunikasi Orangtua dengan Anak,” Jurnal Al Murabbi 5, no. 2 (2019). h. 141.
} 
substansi kegiatan, pelaksana kegiatan dan pihak-pihak yang terkait, mekanisme pelaksanaan, keorganisasian, waktu dan tempat, serta fasilitas pendukung.

Rumusan budaya madrasah dalam pendidikan adab diambil dari norma, nilai, keyakinan yang disepakati memiliki kekuatan yang mampu mendorong dan menginspirasi stakehlolder untuk pendidikan adab siswa. Tahapannya meliputi: 1) Mengidentifikasi jenis-jenis nilai budaya madrasah yang dapat direalisasikan; 2). Mengembangkan rancangan pelaksanaan budaya madrasah termasuk bentuk pembinaan terhadap pelanggarnya; 3). Menyiapkan fasilitas pendukung pelaksanaan budaya madrasah; 4). Melaksankan sosialisasi budaya madrasah terhadap seluruh komponen madrasah.

Perencanaan budaya madrasah MIN Demangan Madiun dalam pendidikan adab adalah sebagai berikut: (a) Perencanaan Budaya Adab di lingkungan Madrasah MIN Demangan Kota Madiun terdiri dari:

Tabel. 1.1

Perencanaan Budaya Madrasah dalam Hal Ibadah

\begin{tabular}{|l|l|l|l|}
\hline No & \multicolumn{1}{|c|}{ Bentuk } & \multicolumn{1}{|c|}{ Kriteria } & \multicolumn{1}{|c|}{ Pembinaan } \\
\hline 1 & Sholat dan Wudlu & $\begin{array}{l}\text { Sungguh-sungguh \& } \\
\text { sempurna }\end{array}$ & $\begin{array}{l}\text { Mengulang wudlu \& Sholat } \\
\text { setelah jamaah }\end{array}$ \\
\hline 2 & Memuliakan Masjid & Khidmad \& berdzikir & $\begin{array}{l}\text { Menghafal bacaan sholat/ Juz } \\
\text { 'amma ba'da sholat di masjid }\end{array}$ \\
\hline
\end{tabular}

Tabel. 1.2

Perencanaan Budaya Madrasah dalam Hal Kebersihan dan Ketertiban

\begin{tabular}{|c|c|c|c|}
\hline No & Bentuk & Kriteria & Pembinaan \\
\hline 1 & Cara berpakaian & $\begin{array}{l}\text { Berpakaian \& } \\
\text { berpenampilan rapi \& } \\
\text { bersih }\end{array}$ & 1. Membetulkan segera \\
\hline 2 & Pemakaian Seragam & $\begin{array}{l}\text { Berseragam dan beratribut } \\
\text { lengkap }\end{array}$ & $\begin{array}{ll}\text { 1. } & \text { Diperingatkan } \\
\text { 2. } & \text { Menghadap Korbid. } \\
\text { Kedisiplinan Siswa }\end{array}$ \\
\hline 3 & $\begin{array}{l}\text { Penempatan alas } \\
\text { kaki }\end{array}$ & $\begin{array}{l}\text { Meletakkan di rak yang telah } \\
\text { tersedia }\end{array}$ & $\begin{array}{l}\text { 1. Diperingatkan } \\
\text { 2. Diambil dan diberikan ke } \\
\text { Waka Kesiswaan }\end{array}$ \\
\hline 4 & $\begin{array}{l}\text { Perhatian terhadap } \\
\text { barang Pribadi }\end{array}$ & Diberi identitas & 1. Segera menuliskan identitas \\
\hline 5 & $\begin{array}{l}\text { Kepedulian } \\
\text { terhadap sampah }\end{array}$ & Membuang di tempatnya & $\begin{array}{ll}\text { 1. Dinasihati } \\
\text { 2. Mengambili sampah satu tas } \\
\text { kresek. }\end{array}$ \\
\hline
\end{tabular}

Tabel 1.3.

Perencanaan Budaya Madrasah dalam Hal Perilaku Sosial

\begin{tabular}{|l|c|c|c|}
\hline No & Bentuk & Kriteria & Pembinaan \\
\hline
\end{tabular}




\begin{tabular}{|c|c|c|c|}
\hline 1 & $\begin{array}{l}\text { Sikap terhadap } \\
\text { sesama }\end{array}$ & $\begin{array}{l}\text { Membiasakan } 5 \text { S (Senyum, } \\
\text { Salam, Sapa, Sopan \& santun ) }\end{array}$ & 1. Diberi pengertian \\
\hline 2 & $\begin{array}{l}\text { Sikap terhadap } \\
\text { Guru }\end{array}$ & $\begin{array}{l}\text { 1. Berbahasa yang baik } \\
\text { 2. Berjabat tangan jika } \\
\text { berjumpa } \\
\text { 3. Membungkukkan badan jika } \\
\text { lewat di depannya dan } \\
\text { berkata permisi }\end{array}$ & 2. Diberi pengertian \\
\hline 3 & Perkataan & $\begin{array}{l}\text { 1. Menghindari perkataan kotor } \\
\text { 2. } \\
\text { Berkata jujur }\end{array}$ & $\begin{array}{l}\text { 1. Menulis kata-kata baik } \\
\text { sebanyak } 50 \mathrm{X}\end{array}$ \\
\hline 4 & Perbuatan & 1. Tidak berkelahi & $\begin{array}{l}\text { 1. Berkelahi } 1 \mathrm{X} \text { diperingatkan } \\
\text { 2. Berkelahi } 2 \mathrm{X} \text { diperingatkan } \\
\text { tertulis } \\
\text { 3. Berkelahi } 3 \mathrm{X} \text { diskors } 1 \text { hari } \\
\text { Berkelahi lebih dari } 3 \mathrm{X} \\
\text { diskors } 1 \text { minggu. }\end{array}$ \\
\hline
\end{tabular}

Tabel. 1.4

Perencanaan Budaya Madrasah dalam Hal Makan dan Minum

\begin{tabular}{|l|l|ll|l|}
\hline No & \multicolumn{1}{|c|}{ Bentuk } & \multicolumn{1}{|c|}{ Kriteria } & \multicolumn{1}{|c|}{ Pembinaan } \\
\hline 1 & Makan dan Minum & 1. & Cuci Tangan & Diperingatkan \\
& & 2. & Berdo'a & Diperingatkan \\
& & 3. & Makan sambil duduk & Jajan disuruh \\
& & 4. & tidak bicara berlebihan & mengembalikan \\
& & 5. & Menggunakan tangan kanan & \\
& & 6. & Membeli jajan pada waktunya & \\
\hline
\end{tabular}

Tabel. 1.5

Perencanaan Budaya Madrasah dalam Hal Ketertiban

\begin{tabular}{|c|c|c|c|}
\hline No & Bentuk & Kriteria & Pembinaan \\
\hline 1 & Kehadiran & $\begin{array}{l}\text { 1. Hadir di Madrasah } \\
\text { tepat waktu } \\
\text { 2. Berjabat tangan } \\
\text { dengan guru dengan } \\
\text { senyum }\end{array}$ & $\begin{array}{l}\text { 1. Terlambat } 1 \mathrm{X} \text { diberi peringatan } \\
\text { 2. Terlambat } 2 \mathrm{X} \text { berturut-turut } \\
\text { menuliskan kata-kata yg baik } 25 \mathrm{X} \\
\text { 3. Terlambat } 3 \mathrm{X} \text { berturut-turut } \\
\text { mencari nasehat dan tanda tangan } 5 \\
\text { guru }\end{array}$ \\
\hline 2 & Masuk Kelas & $\begin{array}{l}\text { 1. Masuk kelas tepat } \\
\text { waktu setelah istirahat }\end{array}$ & $\begin{array}{l}\text { Keterlambatan karena siswa bermain } 1 \mathrm{X} \\
\text { diperingatkan. Lebih meminta nasehat } \\
\text { dan tanda tangan } 5 \text { guru }\end{array}$ \\
\hline 3 & Antri & $\begin{array}{l}\text { 1. Membiasakan budaya } \\
\text { antri }\end{array}$ & $\begin{array}{l}\text { 1. Ditempatkan di barisan paling } \\
\text { belakang }\end{array}$ \\
\hline 4. & Bermain & $\begin{array}{ll}\text { 1. } & \text { Bermain di tempatnya } \\
\text { 2. Tidak berlarian di } \\
\text { kelas dan teras kelas } \\
\text { 3. Tidak bermain waktu } \\
\text { pelajaran }\end{array}$ & $\begin{array}{l}\text { 1. Diperingatkan } \\
\text { 2. Alat permainan diambil } \\
\text { 3. Diperingatkan \& disuruh mengambil } \\
\text { sampah } 1 \text { kresek }\end{array}$ \\
\hline 5 & Lain-lain & 1. Tidak membawa HP & $\begin{array}{l}\text { 1. HP diambil dan dapat diambil oleh } \\
\text { orang tua }\end{array}$ \\
\hline
\end{tabular}

b). Perencanaan Budaya Madrasah Dalam Pendidikan Adab di Kelas MIN Demangan Kota Madiun sebagai meliputi: (1) masuk kelas jam pertama 
berbaris di depan kelas dan masuk berjabat tangan dengan guru dan sesama teman; (2) mengaji bersama dalam waktu 5 menit sebelum jam pelajaran pertama dimulai di bawah panduan ustadz, ustadzah; (3) siswa meminta ijin kepada ustadz atau ustadzah setiap akan meninggalkan atau masuk kelas pada saat jam pelajaran dengan mengenakan Pin; (4) guru memulai pelajaran setelah kelas bersih dan rapi; (5) membuang sampah di tempatnya; (6) setiap guru memberi tanda mengangkat tangan kanan dengan telapak tangan menghadap ke depan, siswa diam dan konsentrasi; (7) berdo'a bersama sesudah pelajaran terakhir selesai; (8) berjabat tangan dengan guru saat meninggalkan kelas pada jam terakhir; (9) menerapkan budaya datang bersih pulang bersih.

b. Pelaksanaan Penguatan Budaya Madrasah dalam Pendidikan Adab di MIN Demangan Kota Madiun

Pada tahap pelaksanaan diawali dengan pengorganisasian budaya madrasah dalam pendidikan adab merupakan tahapan awal mengimplementasikan perencanan budaya madrasah yang telah disepakati. Pada tahapan ini diperlukan tanggung jawab dan partisipasi aktif dari semua unsur madrasah yang meliputi kepala madrasah, guru, komite, orang tua, dan siswa.

Selanjutnya melakukan koordinasi dari pelaksana kegiatan sehingga diperoleh intergrasi dan kerjasama yang sinergis antara pimpinan sekolah, guru, karyawan dan murid, wali murid dan komite madrasah.

Terbentuknya adab pada manusia tidak terlepas dari kebiasaan (babitus) yang dilakukan sehari-hari. Seseorang yang hidup dalam keluarga yang memiliki kebiasaan tertib melaksanakan shalat lima waktu berjamaah misalnya, maka akan cenderung membentuk dirinya beradab yakin disiplin melaksanakan shalat lima waktu berjamaah, demikian sebaliknya. Ada ungkapan kaitan antara kebiasaan dan adab, yaitu: "hati-hati dengan perkataan, karena ia akan mendorong pada perbuatan. Hati-hati dengan perbuatan, karena ia akan mendorong pada kebiasaan. Hati-hati dengan kebiasaan, karena ia akan mendorong pada adab yang permanen dalam diri manusia."

Pelaksanaan budaya madrasah dalam pendidikan adab merupakan salah satu pembiasaan (babitus) tindakan, sikap dan pola pikir tertentu terhadap para siswa dalam kehidupan sehari-hari di madrasah dalam waktu yang lama. Pembiasaan adab siswa yang berulang-ulang setiap hari dalam waktu yang cukup lama akan mampu menghasilkan adab siswa sesuai dengan nilai yang diinginkan.

Iklim lingkungan (condisioning) memberikan andil yang besar terhadap pendidikan adab anak karena memiliki dampak besar terhadap keberhasilan pendidikan nilai-nilai adab. Lingkungan madrasah dengan sistem nilai yang dianutnya, berdampak pada sikap dan paradigm hidup manusia dalam komunitas nya. Jika sistem nilai dan pandangan mereka terbatas pada saat disini dan kedisinian, maka upaya dan usahanya terbatas pada saat ini dan di sini pula. 
al-Qur'an dalam banyak ayatnya menekankan tentang kebersamaan antar anggota masyarakat menyangkut pengalaman sejarah yang sama, tujuan bersama, gerak langkah yang sama, solidaritas yang sama. Muncul ajaran tentang amar ma'ruf dan nahi munkar, dan tentang fardhu kifayah, tanggung jawab bersama dalam menegakkan nilai-nilai yang baik dan mencegah nilai-nilai yang buruk.

Madrasah adalah lembaga yang membimbing, membina proses pendidikan yang berorientasi pada nilai (value-oriented enterprise). Bahwa organisasi madrasah merupakan suatu sistem didalamnya yang mengusahakan pendidikan pegadaban untuk mengontrol pola perkembangan pendidikan manusia mencapai kesempurnaan fisik, kesempurnaan taraf berfikir, kesempurnaan adab perilaku berdasarkan pertimbangan emosional dan spiritual yang diyakininya.

Berdasarkan uraian di atas dapat dianalisis bahwa pendidikan adab seseorang sangat dipengaruhi kebiasaan, teladan dan iklim lingkungan yang mengitari manusia dalam tempo waktu yang lama. Madrasah merupakan lingkungan yang sangat baik dan sangat berperan dalam proses internalisasi pendidikan adab. Tidak kurang dari enam jam dalam sehari, waktu anak di madrasah, oleh karena itu, budaya dalam madrasah berupa perencanaan program yang diterapkan, habitus, lingkungan, dukungan rolemodel stakeblolder (teladan) dan lingkungan sosial akan sangat memiliki dampak yang besar dalam pembentukan adab siswa, lebih-lebih dalam usia pendidikan dasar, yang memiliki pola pikir masih sederhana, yang seringkali meniru apa saja yang dilihatnya (imitation).

c. Monitoring dan Evaluasi

Tahap selanjutnya penguatan budaya madrasah dalam pendidikan adab adalah monitoring dan evaluasi. Kegiatan monitoring dan evaluasi dilaksanakan secara konsisten dan terjadwal dalam kalender pedidikan dan berkesinambungan. Kegiatan ini membahas permasalahan-permaslahan yang menjadi temuan di lapangan saat proses pendidikan didalam dan diluar sekolah untuk ditindaklanjuti berupa dicarikan solusi pemecahannya, sehingga permasalahan dan strategi pemecahan masalah teridentifikasi dan terumuskan dengan baik. Diharapkan dengan demikian akan memperoleh hasil yang lebih baik secara berkelanjutan.

d. Tindak Lanjut pengembangan.

Pada tahap tindak lanjut dimulai dengan melakukan inventariasi hembatan-hambatan yang dijumpai dalam pelaksanaan dan juga menganalisis bentuk budaya madrasah dalam pendidakan adab yang telah dapat terlaksana dengan baik maupun budaya madrasah dalam pendidikan adab yang sulit direalisasikan. Hasil inventarisasi kemudian dianalisis selanjutnya dijadikan sebagai bahan pengembangan perumusan kembali budaya madrasah pada tahuntahun berikutnya dan begitu selanjutnya sesuai dengan alur PDCA yakni Planning (direncanakan) Do (dilaksanakan), C (Controlling) dimonitor dan dievaluasi, dan Action (ditindaklanjuti). Melalui manajemen strategis seperti ini diharapkan nilai- 
nilai yang dikembangkan melalui budaya madrasah dalam pendidikan adab berhasil dan terus ditingkatakan secara berkelanjutan.

\section{Hasil Penguatan Budaya Madrasah dalam Pendidikan Adab di MIN Demangan Madiun}

Program budaya madrasah dalam pendidikan adab di MIN Demangan Kota Madiun berdasarkan hasil wawancara, observasi dan dokumentasi diperoleh sebagai berikut. (a). Salah satu prestasi yang diraih oleh MIN Demangan Kota Madiun adalah Terbaik I dalam Lomba Widya Pakarti Nugraha jenjang SD/MI tingkat propinsi Jawa Timur. Widya Pakarti Nugraha merupakan sebuah penghargaan prestisius bagi madrasah yang telah menunjukkan kinerja yang baik dalam upaya menanamkan dan mengimplementasikan pendidikan adab atau karakter di madrasah dan lingkungannya. Lomba itu digelar dalam rangka mensosialisasikan dan memotivasi implementasi program pendidikan adab. Hal ini merupakan indikator nyata akan keseriusan MIN Demangan dalam merencanakan dan melaksanakan, mengevaluasi, mengenalikand an mengembangkan budaya pendidikan adab di lembaga tersebut. Pendidikan adab meupakan investasi yg sangat berharga untuk mewujudkan generasi yang unggul dalam moral dan profesional dalam semua bidang berdasarkan bakat dan minatnya. (b). Teraihnya Juara III Lomba Linngkungan Sekolah Sehat (LLSS) Tingkat Nasional jenjang SD/MI tingkat Nasional. Predikat ini merupakan bukti bahwa MIN Demangan konsen menerapkan pendidikan adab siswa bidang kebersihan dan kepedulian lingkungan secara serius. Penilaian ini dititik beratkan pada perilaku hidup bersih dan sehat (PHBS) pada warga madrasah.

\section{Catatan Akhir}

Berdasarkan hasil pembahasan model manajemen startegis pendidikan adab anak usia pendidikan dasar di Indoensia yang dalam hal ini studi di MIN Demangan Kota Madiun adalah sebagai berikut. (1). Menggunakan tahapan perencanaan dan penetapan, pelaksanaan diawali dengan pengorganisasian, koordinasi dari pelaksana kegiatan sehingga diperoleh intergrasi dan kerjasama yang sinergis antara pimpinan sekolah, guru, karyawan, siswa, orang tua dan komite madrasah. Hal ini akan menghasilkan terbentuknya adab pada stakeholder yang tidak terlepas dari kebiasaan (babitus) yang dilakukan sehari-hari dalam lingkungan sosial tertentu dengan iklim lingkungan yang kondusif sehingga melahirkan adab yang mulia.

Tahap selanjutnya penguatan budaya madrasah dalam pendidikan adab adalah monitoring dan evaluasi. Kegiatan monitoring dan evaluasi dilaksanakan secara konsisten terjadwal dalam kalender pedidikan secara kontinue. Pada tahap tindak lanjut dilakukan dengan inventariasi hembatan-hambatan yang dijumpai dalam pelaksanaan dan juga menganalisis bentuk budaya madrasah dalam pendidakan adab yang telah dapat terlaksana dengan baik maupun budaya madrasah dalam pendidikan adab yang sulit 
direalisasikan. Hasil inventarisasi kemudian dianalisis selanjutnya dijadikan sebagai bahan pengembangan perumusan kembali budaya madrasah pada tahun-tahun berikutnya.

Sedangkan hasil budaya madrasah dalam pendidikan adab di MIN Demangan Kota Madiun menperleh prestasi terbaik I dalam Lomba Widya Pakarti Nugraha jenjang SD/MI tingkat propinsi Jawa Timur. Widya Pakarti Nugraha merupakan sebuah penghargaan prestisius bagi madrasah yang telah menunjukkan kinerja yang baik dalam upaya menanamkan dan mengimplementasikan pendidikan adab atau karakter di madrasah dan lingkungannya. Hal ini merupakan indikator nyata akan keseriusan MIN Demangan dalam merencanakan dan melaksanakan, mengevaluasi, mengenalikan dan mengembangkan budaya pendidikan adab di lembaga tersebut. (b). Teraihnya Juara III Lomba Linngkungan Sekolah Sehat (LLSS) Tingkat Nasional jenjang SD/MI tingkat Nasional. Predikat ini merupakan bukti bahwa konsen penerapan pendidikan adab siswa bidang kebersihan dan kepedulian lingkungan secara serius yang penilaian ini dititik beratkan pada perilaku hidup bersih dan sehat (PHBS) pada warga madrasah.

\section{Daftar Rujukan}

Acetylena, Sita. "Analisis Implementasi Kebijakan Pendidikan Karakter Di Perguruan Taman Siswa Kecamatan Turen Kabupaten Malang." Jurnal Kebijakan dan Pengembangan Pendidikan 1, no. 1 (2013): 56.

Acikgence, Apparslan. Islamic Science Towards A Definition. Kuala Lumpur: ISTAC, 2003.

Ann McLachlan, D. "The Impact of Globalization on Internationally Mobile Families: A Grounded Theory Analysis.” Journal of Theory Construction \& Testing 9, no. 1 (t.t.).

Attas, S.M.N. al-. "Risalah Untuk Kaum Muslimin (Message to Muslims)." A long manuscript dictated to his secretary. Para, Maret 1973.

Baharuddin, Baharuddin. Pendidikan dan Psikologi Perkembangan. Yogyakarta: Ar-Ruzz Media, 2014.

Hartini, Sri. "Pendidikan Karakter Disiplin Siswa di Era Modern Sinergi Orang Tua dan Guru di MTS Negeri Kabupaten Klaten." AL-ASASIYYA: Journal Of Basic Education 2, no. 1 (2017): 38-59.

Karo-Karo, D. E. M. M. U. "Membangun Karakter Anak dengan Mensinergikan Pendidikan Informal dengan Pendidikan Formal." Elementary School Journal PGSD FIP UNIMED 1, no. 2 (2014): 1-3.

Katni, Katni. "Jilbab Dalam Al-Qur'an Dan Al-Hadits Serta Aplikasinnya Pada Pendidikan Islam Perspektif Teori Habitus Pierre Bourdieu." Al-ASASIYYA: Journal Of Basic Education 01, no. 01 (2016): 58.

Laksana, Sigit Dwi. "Urgensi Pendidikan Karakter Bangsa di Sekolah." Jurnal Muaddib 05, no. 01 (2015): 137.

Machmud, Muslimin. Tuntunan Penulisan Tugas Akbir Berdasarkan Prinsip Dasar Penelitian Ilmiah. Malang: Selaras, 2016.

Mustofa, Imam. "Keluarga Sakinah dan Tantangan Globalisasi." Al-Mawarid Journal of Islamic Law XVIII (2008): 227-48.

Rianto, Hadi. "Implementasi Nilai Kemanusiaan Yang Adil Dan Beradab Di Lingkungan Sekolah.” Sosial Horizon: Jurnal Pendidikan Sosial 3, no. 1 (2016): 8091. 
Roshonah, Adiyati Fathu. "Urgensi Program Pelatihan Parenting dalam Meningkatkan Kemampuan Komunikasi Orangtua dengan Anak." Jurnal Al Murabbi 5, no. 2 (2019): 25.

Undang-Undang Republik Indonesia No. 20 Tabun 2003 Tentang Sistem Pendidikan Nasional. Bandung: Citra Umbara, 2003. 